Artikel Riset

DOI : $10.33751 /$ jf.v8i1.1170
Fitofarmaka Jurnal Ilmiah Farmasi

Vol. 8, No.1, Juni 2018 : 43-49

p-ISSN : 2087-9164 e-ISSN : 2622-755X

\title{
PENGARUH ANTIBIOTIKA PROFILAKSIS TERHADAP KEJADIAN INFEKSI LUKA OPERASI
}

\author{
Oktaviana Zunnita* \\ Program Studi Farmasi, FMIPA, Universitas Pakuan, PO Box 452 Bogor 16143, \\ West Java, Indonesia \\ *E-mail: nadiahasna40@gmail.com
}

Diterima : 13 Mei 2018

Direvisi : 28 Mei 2018

Disetujui : 11 Juni 2018

\begin{abstract}
ABSTRAK
Antibiotik profilaksis adalah antibiotik yang diberikan pada pasien yang akan menjalani pembedahan untuk mencegah terjadinya infeksi akibat tindakan operasi. Antibiotik profilaksis diberikan secara intravena agar dicapai konsentrasi maksimum di serum/jaringan pada saat operasi. Pemilihan antibiotika profilaksis yang sesuai pada tindakan pembedahan sangat menentukan keberhasilan dalam mencegah terjadinya infeksi luka operasi. Penelitian ini bertujuan untuk mengetahui besarnya angka kejadian infeksi luka operasi dan mengevaluasi penggunaan antibiotika profilaksis dalam pencegahan infeksi luka operasi di rumah sakit Premier Bintaro, Kota Tanggerang. Jenis penelitian ini adalah observasional dengan rancangan studi deskriptif analitik melalui penelusuran data yang dilakukan secara retrospektif pada pasien yang menjalani pembedahan di ruang operasi. Analisa dan evaluasi data berupa deskripsi pola penggunaan antibiotika profilaksis dan angka kejadian infeksi luka operasi serta hubungan antara penggunaan antibiotika profilaksis dengan kejadian infeksi luka operasi. Hasil yang diperoleh dalam penelitian ini menunjukan bahwa angka kejadian infeksi luka operasi pada tindakan pembedahan sebanyak 7 kasus $(1,97 \%)$ dari jumlah total 355 kasus bedah pada periode penelitian. Antibiotika profilaksis yang paling banyak digunakan adalah sefalosporin generasi III (66,2\%). Hasil Analisa dengan Fisher exact menunjukkan bahwa sifat operasi jenis antibiotika dan waktu pemberian antibiotika mempunyai hubungan bermakna dengan kejadian ILO $(\mathrm{p}<0,05)$. Dari penelitian terlihat pula bahwa semakin lama operasi berlangsung semakin tinggi risiko infeksi luka operasi. Antibiotika sefalosporin generasi III terbanyak yang digunakan adalah ceftriaxone injeksi.
\end{abstract}

Kata kunci: Antibiotika profilaksis, sefalosporin, luka operasi

\section{EFFECT OF PROPHYLAXIS ANTIBIOTICS TO THE OCCURANCE OF SURGICAL SITE INFECTION}

\begin{abstract}
Antibiotic prophylaxis commonly given to the patients undergoing surgery to prevent infection due to surgery wound. Antibiotics prophylactic were given intravenously to achieve maximum serum/tissue concentration at the time of operation and the maximum level was maintained during the surgical procedure. Selection of appropriate antibiotic prophylaxis in surgery is crucial to prevent surgical procedure.
\end{abstract}


Selection of appropriate antibiotic prophylaxis in surgery is crucial to prevent surgical site infection. This study aims to determine the occurrence of surgical site infection and to evaluate the use of prophylactic antibiotics to the pationts undergoing surgery in Premier Bintaro Hospital, Kota Tanggerang hospital. The study was an observational study with descriptive analytic design using retrospective data obtained from the surgery patients. The data was analyzed and evaluated in form of the pattern of antibiotic prophylaxis usage, occurrence of surgical site infection, and relationship between antibiotic prophylaxis usage and occurrence of surgical site infection. The results obtained that during the study period, seven cases of surgical site infections occurred from the total of 355 surgical procedure (1.97\%). The antibiotics prophylaxis most widely used was a third generation cephalosporin (66.2\%) The results of Fisher exact analysis showed that the types of operation, type of antibiotic, and time of antibiotics administration had significant relationship with ILO ( $<<0,05)$. The research also revealed that the longer the surgery time, the higher the risk of surgical site infection. The third generation cephalosporin antibiotics used were ceftriaxone injection was the third generation cephalosporin widely used in hospital.

Key words: Antibiotics prophylactic, cephalosporin, surgical site infection

\section{PENDAHULUAN}

Pasien yang menjalani operasi mempunyai risiko tinggi mengalami infeksi luka operasi dan pemberian antibiotika profilaksis dapat menurunkan infeksi luka operasi. Antibiotik profilaksis diberikan sedemikian rupa sehingga dicapai konsentrasi maksimum di serum/jaringan pada saat awal sayatan bedah, dan kadar ini dijaga selama periode rentan dalam prosedur yaitu waktu antara sayatan kulit dan penutupan kulit (Burke dan Cunha, 2009). Antibiotik profilaksis harus dapat memotong aktifitas patogen terhadap luka yang terkontaminasi atau pada daerah operasi. Menurut World Health Organization (WHO, 2002), antibiotika profilaksis diberikan secara intravena satu jam sebelum pembedahan. National Surgical Infection Prevention Project menyatakan bahwa antibiotika profilaksis sebaiknya tidak digunakan lebih dari 24 jam setelah penutupan luka operasi. Penggunaan antibiotika melebihi 48 jam tidak efektif dalam menurunkan risiko infeksi, dan meningkatkan resistensi antimikroba serta reaksi kolitis (Gordon, 2006).

Pada umumnya, antibiotika profilaksis dianjurkan hanya untuk tindakan dengan kejadian infeksi yang tinggi dan tindakan dengan konsekuensi infeksinya sangat serius. Infeksi luka operasi atau ILO merupakan bagian dari infeksi nosokomial dan termasuk salah satu masalah kesehatan yang cukup serius di rumah sakit. Infeksi pada operasi terjadi karena masuknya kuman yang berasal dari luar atau dari permukaan tubuh ke dalam luka (infeksi eksogen) dan dapat pula karena masuknya kuman yang berasal dari dalam rongga tubuh ke dalam luka (infeksi endogen). Infeksi eksogen terjadi melalui udara, kontak langsung antara luka dengan kuman yang ada pada permukaan tubuh, atau kuman yang berasal dari alat dan tangan. Infeksi endogen umumnya berasal dari tumpahan isi rongga/ saluran sewaktu dinding rongga/ saluran itu dipotong/robek Infeksi ini terjadi pada masa setelah operasi yang ditandai dengan adanya nanah, peradangan, bengkak, rasa nyeri dan panas. Beberapa faktor penderita yang 
mempermudah terjadinya ILO ialah obesitas, diabetes, co-morbid/ penyakit penyerta,_infeksi di tempat lain, kontaminasi dalam pembedahan, rawat inap pre-operatif yang panjang, karier Staphylococcus aureus, dan pertahanan tubuh yang lemah. Faktor kuman yang mempengaruhi terjadinya ILO ialah virulensi serta jumlah kuman. Faktor lokal yang dapat mempermudah infeksi luka adalah pembedahan yang lama (> 4 jam), adanya bekuan darah atau jaringan nekrotik yang tertinggal, vaskularisasi yang buruk karena jahitan yang terlalu rapat dan kuat, jenis benang, dan pemasangan drain (Sjamsuhidajat et al., 2010). Di Indonesia, angka kejadian ILO pada rumah sakit bervariasi antara 2$18 \%$ dari keseluruhan prosedur pembedahan.

Pada studi ini, pengumpulan data penggunaan antibitiotik profilaksis dilakukan dengan melihat penggunaan antibiotika profilaksis meliputi jenis antibiotik, rute pemberian, lama penggunaan, lama operasi, jangka waktu pemberian dan angka kejadian luka operasi.

\section{METODE PENELITIAN Bahan}

Bahan pada penelitian ini adalah data dari rekam medis 355 pasien dengan kasus bedah yang menjalani operasi dan perawatan di RS Premier Bintaro, Kota Tanggerang. Parameter data rekam medik pasien yang dilihat adalah sifat operasi, lama penggunaan antibiotika, waktu operasi, jenis antibiotik dan waktu pemberian antibiotika. Kejadian luka infeksi luka paska bedah ditandai dengan adanya nanah/pus berdasarkan diagnosa dokter yang tertera dalam rekam medik pasien dilihat dalam waktu 30 hari. Kriteria Inklusi sampel adalah pasien yang menjalani operasi dan perawatan di
Rumah Sakit pada periode penelitian. Eklusi sampel adalah pasien yang tidak dapat diikuti perkembangan atau data rekam medik tidak terbaca serta pasien dengan daya tahan menurun (HIV/AIDS).

\section{Metode Analisa}

Penelitian ini merupakan penelitian deskriptif yang dilakukan secara retrospektif pada pasien yang menjalani operasi di rumas sakit Premier Bintaro, Kota Tangerang pada Mei 2011 - April 2012. Data dilihat dari beberapa definisi operasional mulai dari jenis antibiotika profilaksis yang diberikan sebelum operasi berdasarkan nama generik dilihat dari golongan antibiotika yang digunakan, seperti sefalosporin generasi 2, generasi 3, generasi 4, carbapenem dan seterusnya. Jarak pemberian antibiotika profilaksis pada pasien sebelum operasi dilihat dari ketepatan waktu pemberian profilaksis 60 menit atau lebih. Durasi penggunaan antibiotika profilaksis dilihat dari lamanya penggunaan antibiotika. Penggunaan antibiotika profilaksis digunakan dalam 24 jam atau lebih. Waktu Operasi yang diperlukan oleh pasien untuk menjalani operasi juga merupakan salah satu kategori yang dilihat dalam penelitian. Waktu operasi berlangsung < 1jam atau lebih. Sifat operasi digolongkan dalam beberapa kategori yaitu bersih, kontaminasi dan kotor. Data yang diperoleh kemudian dikelompokkan dan dianalisis. Hubungan antara kejadian infeksi luka dengan beberapa data-data yang diambil dilakukan dengan analisa fisher exact.

\section{HASIL DAN PEMBAHASAN}

Hasil yang diperoleh dalam penelitian ini menunjukan bahwa angka kejadian infeksi luka operasi pada tindakan pembedahan sebanyak 7 
kasus (1,97\%) dari jumlah total 355 kasus bedah pada periode penelitian. Dari hasil pengamatan infeksi luka operasi dalam penelitian ini sifat operasi, jenis antibiotika, waktu pemberian dan lama operasi memperlihatkan adanya hubungan atau pengaruh dalam kejadian infeksi luka operasi. Kejadian infeksi luka operasi terjadi pada operasi bersih 1,13\% yaitu pada operasi cranioplasty, koreksi scoliasis dan Stabilisasi Bone/Other Operations Bone serta ORIF (Open reduction Invasif Fraktur). Operasi kontaminasi $0,56 \%$ yaitu pada operasi appendectomy dan laparatomi. Operasi kotor 0,28\% yaitu pada operasi Close reduction+ debridement+ internal fixasi.

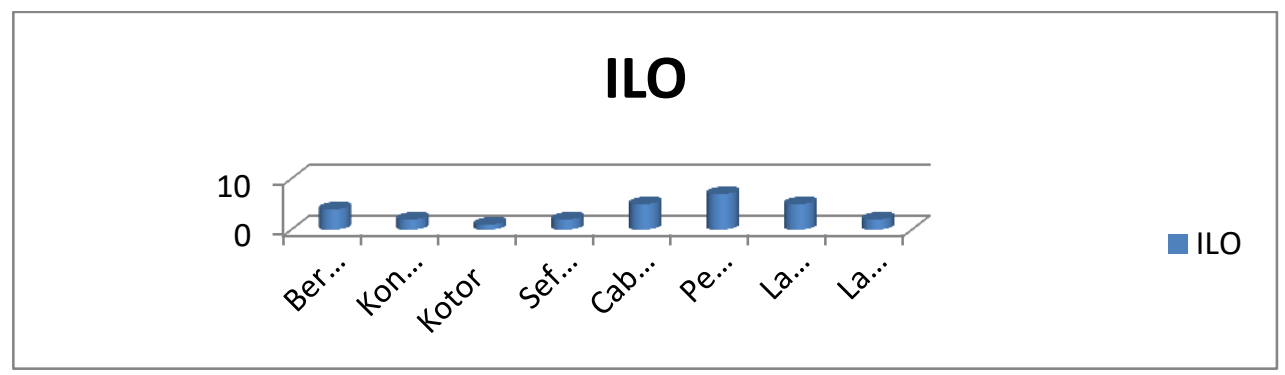

\section{Gambar 1. Infeksi Luka Operasi Pada Sifat Operasi, Jenis Antibiotika, Waktu Pemberian dan Lama Operasi}

Dari gambar diatas, didapat hasil infeksi luka operasi terjadi pada sifat operasi bersih 4 pasien, kontaminasi 2 pasien dan kotor 1 pasien. Infeksi luka operasi juga terjadi pada pemberian antibiotika profilaksis tidak tepat waktu, dengan lama operasi yang berlangsung 12 jam atau lebih dari 2 jam. Pada jenis antibiotika profilaksis yang digunakan, ada 5 kejadian infeksi luka yang disebabkan oleh pemakaian antibiotika golongan carbapenem (meropenem). Hal ini bisa disebabkan waktu paruh dari, antibiotika golongan ini adalah pendek yaitu 1 jam, sehingga tidak direkomendasikan dalam pembedahan, selain harganya yang mahal, antibiotika ini mempunyai resiko lebih besar untuk kejadian infeksi luka operasi apabila pemberian profilaksis tidak tepat waktu dan operasi berlangsung lama, sehingga kadar obat dalam darah sudah berkurang saat operasi berlangsung. Infeksi luka operasi terjadi pada 2 pasien dengan penggunaan antibiotika profilaksis golongan sefalosporin generasi 3, hal ini dapat disebabkan oleh pasien sudah mengalami infeksi sebelum operasi, sehingga dibutuhkan kombinasi antibiotika profilaksis, dan pemberian profilaksis harus tepat waktu dengan operasi berlangsung $>1$ jam agar manfaat profilaksis optimal.

Pada penelitian sebelumnya yang dilakukan oleh Amba (2007), infeksi luka operasi paling tinggi juga terjadi pada durasi operasi $>2$ jam yaitu sebesar 11,3 $\%$, pada durasi $1-2$ jam $8,4 \%$ dan pada durasi operasi 1 jam $0 \%$. Oleh karena itu dapat disimpulkan bahwa semakin lama operasi berlangsung kemungkinan terjadi infeksi luka operasi cukup besar. Dari hasil penelitian dapat dikatakan teknik aseptis sudah dilakukan dengan cermat, dan penggunaan antibiotika profilaksis dapat dilihat manfaatnya karena sebagian besar pasien yang menjalani operasi tidak mengalami infeksi luka operasi. Hal ini dapat terlihat bahwa hanya $1,97 \%$ pasien mengalami 
infeksi luka operasi dari 355 sampel pasien yang menjalani pembedahan.

Indikasi penggunaan antibiotika profilaksis lebih ditekankan pada operasi bersih dan bersih kontaminasi dan dasar pemilihan antibiotika profilaksis sesuai dengan sensitivitas dan pola bakteri patogen terbanyak pada kasus yang bersangkutan. Sebaiknya antibiotika profilaksis yang digunakan adalah spektrum sempit untuk mengurangi risiko resistensi bakteri, toksisitas rendah, tidak menimbulkan reaksi merugikan terhadap pemberian obat anestesi, bersifat bakterisidal, harga terjangkau.
Oleh karena itu antibiotik yang disarankan adalah sefalosporin generasi I dan II. Pada kasus tertentu yang dicurigai melibatkan bakteri anaerob dapat ditambahkan metronidazol. Tidak dianjurkan menggunakan sefalosporin generasi III dan IV, golongan karbapenem (dicadangkan untuk kasus yang lebih serius) dan golongan kuinolon untuk profilaksis bedah (cepat memberikan resistensi). Dalam penelitian ini infeksi luka operasi terjadi pada penggunaan antibiotika profilaksi golongan carbapenem adalah $1,41 \%$ dan $0,56 \%$ antibiotika golongan sefaloporin generasi 3 (ceftriaxone).

Tabel 1. Penggunaan Antibitotika Profilaksis Pada Periode Penelitian

\begin{tabular}{cc}
\hline Antibiotika profilaksis & Jumlah pemakaian \\
\hline Sefalosporin generasi 2 & 5 \\
Sefalosporin generasi 3 & 235 \\
Carbapenem & 54 \\
Aminoglikosida & 4 \\
Penicillin & 41 \\
Glikopeptida & 14 \\
Sefalosporin generasi 4 & 2
\end{tabular}

Penggunaan antibiotika profilaksis pada penelitian ini masih banyak menggunaka antibiotika yang biasa digunakan untuk pengobatan di ruang rawat. Hal ini dapat disebabkan karena belum adanya pengaturan dalam pemberian antibiotika profilaksis dan dapat juga karena persediaan obat dipasaran untuk sefalosporin generasi 1 dan 2 dalam bentuk injeksi susah didapat atau bisa juga disebabkan oleh promosi obat antibiotika dari pihak produsen serta sensitifitas antibiotika itu sendiri masih $>60 \%$ di rumah sakit ini.

Berdasarkan hasil penelitian sebanyak 117 (33\%) pasien menerima antibiotika secara intravena tepat waktu dan $238(67 \%)$ pasien menerima antibiotika tidak tepat waktu. Hal ini disebabkan oleh persiapan operasi yang meliputi kedatangan dokter dan kesiapan kamar bedah. Ada beberapa penelitian yang menunjukkan bahwa pemberian dosis tunggal antibiotika profilaksis dengan waktu paruh cukup lama, cukup memadai untuk beberapa operasi (Welmahos et al., 2002 dan Desyana et al., 2008). Pada operasi yang tidak membutuhkan waktu lama, pemberian profilaksis dosis tunggal sama efektifnya dengan pemberian profilaksis dalam waktu lebih dari 24 jam.

Penggunaan antibiotika profilaksis yang tidak rasional dapat meningkatkan 
kejadian resistensi. Rata-rata resistensi antibiotika terjadi di rumah sakit. Pada operasi tertentu, penggunaan antibiotika lebih dari 24 jam setelah operasi direkomendasikan, seperti pada appendectomy, bedah syaraf, arthroplasty dan cardiothoracic (Sign, 2008).
Untuk melihat hubungan antara jenis antibiotika profilaksis, waktu pemberian profilaksis dan lama penggunaan profilaksis dapat dilihat dari hasil analisis dengan fisher exact.

Tabel 2. Kasus ILO Selama Periode Penelitian

\begin{tabular}{|c|c|c|c|c|}
\hline \multirow[t]{2}{*}{ Jenis Operasi } & \multirow[t]{2}{*}{ Sifat Operasi } & \multirow[t]{2}{*}{$\begin{array}{c}\text { Jenis } \\
\text { antibiotika }\end{array}$} & $\begin{array}{l}\begin{array}{l}\text { Waktu } \\
\text { pemberian } \\
\text { antibiotika }\end{array} \\
\text { tepat } \leq 60 \\
\text { menit }\end{array}$ & $\begin{array}{c}\begin{array}{c}\text { Lama } \\
\text { operasi }\end{array} \\
\text { 1. }<1 \text { jam } \\
\text { 2. } 1 \text { - } 2 \text { jam }\end{array}$ \\
\hline & & & $\begin{array}{l}\text { tidak tepat > } \\
60 \text { menit }\end{array}$ & 3. $>2$ jam \\
\hline Laparatomy \& Hemicolectomy Dx & kontaminasi & Meropenem & tidak tepat & 3 \\
\hline Cranioplasty & bersih & Meropenem & tidak tepat & 3 \\
\hline Koreksi scoliosis & bersih & Meropenem & tidak tepat & 3 \\
\hline Appendictomy & kontaminasi & Ceftriaxone & tidak tepat & 2 \\
\hline $\begin{array}{l}\text { Scoliosis, Stabilisasi Bone/Other } \\
\text { Operations Bone }\end{array}$ & bersih & Meropenem & tidak tepat & 3 \\
\hline Orif fraktur tri melaeolar kanan & bersih & Ceftriaxone & tidak tepat & 2 \\
\hline $\begin{array}{l}\text { Close reduction+ debridement+ internal } \\
\text { fixasi }\end{array}$ & kotor & Meropenem & tidak tepat & 3 \\
\hline
\end{tabular}

Tabel 3. Hasil Analisis Korelasi Fisher Exact

\begin{tabular}{|c|c|c|c|c|}
\hline & \multicolumn{3}{|c|}{ Infeksi Luka Operas Hasil Uji Statisti } & \multirow[t]{2}{*}{ Keterangan } \\
\hline & Tidak Ada & Ad & & \\
\hline Sifat Operasi & 348 & 7 & $\mathrm{p}=0,010(\leq 0,05)$ & Berbeda bermakna \\
\hline Jenis antibiotika & 348 & 7 & $\mathrm{p}=0,05 \quad(\leq 0,05)$ & Berbeda bermakna \\
\hline Waktu pemberian antibiot & 348 & 7 & $\mathrm{p}=0,017(\leq 0,05)$ & Berbeda bermakna \\
\hline Lama operasi & 348 & 7 & $\mathrm{p}=0,007(\leq 0,05$ & Berbeda bermakna \\
\hline
\end{tabular}

\section{KESIMPULAN}

Dapat disimpulkan bahwa semakin lama operasi berlangsung kemungkinan terjadi infeksi luka operasi cukup besar. Dari hasil penelitian dapat dikatakan teknik aseptis sudah dilakukan dengan cermat, dan penggunaan antibiotika yang digunakan sebagian besar menggunakan sefalosporin generasi III yaitu sebanyak $235(66,2 \%)$ pasien, carbapenem sebanyak $54(15,2 \%)$ pasien, penicillin $41 \quad(11,5 \%)$ pasien.
Sefalosporin generasi 3 yang banyak dipakai adalah ceftriaxone dan terdapat hubungan dan pengaruh antara sifat operasi, jenis antibiotik, waktu pemberian dan lama operasi dengan infeksi luka operasi dengan $\mathrm{P}$ value $<0,05$.

\section{REFERENSI}

Amba, S. 2007. Hubungan penggunaan antibiotika profilaksis dengan kejadian infeksi luka operasi di ruang bedah IRNA A RSCM 
tahun 2005. Tesis. Universitas Indonesia, Jakarta.

Burke, A. \& M.D. Cunha. 2009. Antibiotic Essentials. 8 th ed. Physicians Press. New DelhiIndia.

Desyana L.S., A. Soemardi \& M. Radji. 2008. Evaluasi penggunaan antibiotika profilaksis di ruang bedah Rumah Sakit Kanker Dharmais Jakarta dan hubungannya dengan kejadian infeksi daerah operasi. Indonesian J. Cancer.

Gordon, S.M. 2006. Antibiotics prophylaxis against postoperative wound infection. Clev. Clin. J. Med. 73: 542-545. CLEV
Sign. 2008. Antibiotic Prophylaxis in Surgery: A national clinical guidelines. United Kingdom.

Sjamsuhidajat, R., W. Karnadihardja, T. Prasetyono \& R. Reno. 2010. Buku Ajar Ilmu Bedah. Edisi 3. Penerbit EGC.

Welmahos, G.C., K.G. Toutouzas, G. Sarkisyan, L.S. Chan \& A. Jindal. 2002. Severe trauma is not an excuse for prolonged antibiotic prophylaxis. Archieves of Surgery. 137(5): 537-41.

WHO. 2001. Prevention of HospitalAcquired Infection. A Practical guide second edition. Malta. Hal. $1-8$ 